\title{
Growth performance of calves fed microbially enhanced soy protein in pelleted starters
}

\author{
N. D. Senevirathne, ${ }^{*}$ J. L. Anderson, ${ }^{\star 1}$ W. R. Gibbons, $†$ and J. A. Clapper \\ *Dairy Science Department, \\ †Biology and Microbiology Department, and \\ ‡Department of Animal Science, South Dakota State University, Brookings 57007
}

\section{ABSTRACT}

Our objective was to determine effects of feeding calves pelleted starters with microbially enhanced (fungi-treated) soy protein (MSP) in replacement of soybean meal (SBM) with different milk replacers (MR). Thirty-six Holstein calves ( 2 d old; 24 females, 12 males) in individual hutches were used in a 12-wk randomized complete block design study. Treatments were (1) MSP pellets with MR formulated for accelerated growth (28\% crude protein, $18 \%$ fat; MSPA), (2) SBM pellets with MR formulated for accelerated growth (SBMA), and (3) MSP pellets with conventional MR (20\% crude protein, 20\% fat; MSPC). Pellets were similar except for $23 \%$ MSP or $23 \%$ SBM (dry matter basis). Pellets and water were fed ad libitum throughout the study. Feeding rates of MR on a dry matter basis were 0.37 $\mathrm{kg}$ twice daily during wk $1,0.45 \mathrm{~kg}$ twice daily during wk 2 to 5 , and $0.45 \mathrm{~kg}$ once daily during wk 6 . Intakes were recorded daily. Body weights, frame size measurements, and jugular blood samples were collected $2 \mathrm{~d}$ every 2 wk at $3 \mathrm{~h}$ after the morning feeding. Fecal grab samples were collected 5 times per d for $3 \mathrm{~d}$ during wk 12 and then composited by calf for analysis of apparent total-tract digestibility of nutrients using acid detergent insoluble ash as an internal marker. Total and starter pellet dry matter intake were greatest for calves fed SBMA and least for MSPC. Calves had similar average daily gain among treatments, but there was a treatment by week interaction and during the last few weeks of the study calves on MSPC had less body weight compared with MSPA or SBMA. Gain-to-feed ratio was similar among treatments; however, there was a treatment by week interaction. Serum glucose was similar among treatments. Plasma urea nitrogen was greatest for calves fed MSPA and least for MSPC. Plasma concentrations of IGF-1 were greatest for calves

Received March 25, 2016.

Accepted September 26, 2016.

${ }^{1}$ Corresponding author: jill.anderson@sdstate.edu fed SBMA. Plasma concentrations of triglycerides were greatest for calves fed MSPC. Plasma concentrations of $\beta$-hydroxybutyrate had a treatment by time interaction. Treatments had similar total-tract dry matter digestibility, but calves fed MSPC had greater crude protein digestibility than SBMA, with MSPA similar to both. Results demonstrated calves fed pelleted starters with MSP had maintained growth performance with less starter intake compared with SBM.

Key words: microbially enhanced soy protein, dairy calf, growth performance

\section{INTRODUCTION}

During the early growth phase of dairy calves, key immunological and digestive system developments are occurring which can affect long-term animal performance (Davis Rincker et al., 2011; Hill et al., 2013). To improve calf performance, high protein milk replacer (MR) and starter feeds have been developed and formulated for accelerated growth. In MR formulated for accelerated growth, most of the proteins are from milk-based sources, which often makes these feeding programs more expensive. However, milk proteins are still most commonly used as they have been shown to result in superior calf performance compared with plant-based proteins (Dawson et al., 1988).

Dry feed intake is also critical to development of an active, functioning rumen. Early consumption of dry feed increases butyrate in the rumen, which is responsible for development of functional ruminal epithelial tissue (Hill et al., 2006). Moreover, Hodgson (1971), Jenny et al. (1982), and Leaver and Yarrow (1972) showed that early dry feed consumption increased reticulorumen development, helped the calf to transition from liquid feed to dry feed, and reduced weaning stress.

A new proprietary processing technique has been developed by Prairie AquaTech (Brookings, SD) in which fungi are used to aerobically process soybean meal (SBM) to increase the protein content, improve digestibility, and decrease anti-nutritional compounds (Gib- 
bons and Brown, 2012). This microbially enhanced soy protein (MSP) has a much greater protein content and digestibility than SBM and has performed comparably to fish meal in aquaculture studies (Sindelar, 2014). It is also believed that fungal cell walls and $\beta$-glucans present in the MSP may give it prebiotic properties (Bruce et al., 2015). Because of its unique nutritional properties, MSP may be a beneficial feed for dairy calves with developing digestive systems.

Research on feeding calves fermented SBM has demonstrated improved immune responses in some cases (Kwon et al., 2011), whereas other trials have shown no improvement (Wolfswinkel, 2009). Lesmeister et al. (2004) reported that supplementing feeds with yeast increased feed component digestibility by increasing microbial activity in the rumen, leading to increased butyrate production. Although MSP has some similarities to fermented SBM, it is produced by an aerobic incubation with a nonyeast fungus, instead of a bacterial or yeast-based fermentation process. Two important compositional differences are that MSP has greater protein content and fewer anti-nutritional factors (antigens, stachyose, raffinose, and trypsin inhibitor) compared with fermented SBM (Gibbons and Brown, 2012).

Our hypothesis was that the improved quantity and quality of protein in MSP, compared with SBM, would allow the former to be used in the starter pellet with conventional MR (20\% CP:20\% fat), and achieve similar or improved calf growth performance compared with SBM used with MR formulated for accelerated growth (28\% CP:18\% fat). We also hypothesized that feeding MSP in pellets with MR formulated for accelerated growth may have additive benefits. The objectives of this research were to conduct a feeding study to determine the effects of MSP in dairy calf starter pellets on growth performance, which was evaluated based on feed intake, BW, body frame size, blood metabolic profile, fecal consistency scores, and apparent total-tract nutrient digestion. As part of this, we also wanted to determine if the increased calf starter pellet $\mathrm{CP}$ from the MSP benefited the calves.

\section{MATERIALS AND METHODS}

\section{Experiment Design}

The research was conducted under protocols approved by the South Dakota State University Institutional Animal Care and Use Committee. Thirty-six newborn Holstein calves (24 females and 12 males) were used in a 12-wk feeding experiment. All calves were housed in individual hutches at the South Dakota State University Dairy Research and Training Facility (Brookings, SD).
Length, width, and height of individual calf hutches were 223, 98, and $133 \mathrm{~cm}$, respectively (Calf-Tec, Hampel Animal Care, Germantown, WI). Wheat straw was used as bedding material. The experiment was conducted from September 2014 to May 2015. Calves were added to the study as they were born. Prior to starting the study all calves received 2 feedings of colostrum at rate of $1.9 \mathrm{~L}$ per feeding. Calf serum blood protein concentrations were tested by refractometer $24 \mathrm{~h}$ after birth, to ensure adequate transfer of immunoglobulins had occurred. Overall mean serum concentration of proteins were $5.4 \pm 0.13 \mathrm{~g} / \mathrm{dL}$. Calves were assigned to 1 of 3 treatments in a randomized block design experiment. Calves were blocked by sex and birthdate. The 3 treatments were (1) MSP pellets with MR formulated for accelerated growth (MSPA), (2) SBM pellets with MR formulated for accelerated growth (SBMA), and (3) MSP pellets with conventional MR (MSPC). The 2 starter pellets were similar composition except for $23 \% \mathrm{SBM}$ or $23 \% \mathrm{MSP}$ on DM basis. Ingredient compositions of the pellets are shown in Table 1.

\section{Management of Calves}

Milk bottles were used to feed MR throughout the preweaning period. During the first 2 wk, calves received MR medicated with $10 \mathrm{mg}$ of neomycin sulfate and $10 \mathrm{mg}$ of oxytetracycline mix. Nonmedicated MR were fed from wk 2 to weaning at 6 wk. During wk 1 , calves were fed twice daily $0.37 \mathrm{~kg}$ of $\mathrm{MR}$ in 2.83 L of water. During wk 2 to 5 , calves received $0.45 \mathrm{~kg}$ of $\mathrm{MR}$ in $2.83 \mathrm{~L}$ of water and $0.45 \mathrm{~kg}$ of $\mathrm{MR}$ once

Table 1. Ingredient composition for calf starter pellets containing soybean meal $(\mathrm{SBM})$ or containing microbially enhanced soy protein (MSP) fed to calves

\begin{tabular}{lcc}
\hline & \multicolumn{2}{c}{ Pellet $^{1}$} \\
\cline { 2 - 3 } Ingredient, \% of DM & SBM & MSP \\
\hline Corn, ground & 35.0 & 35.0 \\
Microbially enhanced soy protein & \\
Soybean meal & - & 23.0 \\
Wheat middling & 23.0 & - \\
Molasses, sugar cane & 35.0 & 35.0 \\
Mineral mix & 5.0 & 5.0 \\
Salt & 1.7 & 1.7 \\
\hline
\end{tabular}

${ }^{1}$ Pellets were custom made by Pipestone Grain Company, Pipestone, MN.

${ }^{2}$ Prairie AquaTech, Brookings, SD.

${ }^{3} 48.2 \%$ dicalcium phosphate; $13.7 \%$ salt; $28.37 \%$ limestone; $3 \%$ selenium $(0.06 \%) ; 5 \%$ ruminant trace mineral mix (2.59\% calcium; $10.64 \%$ magnesium oxide; $1,802 \mathrm{mg} / \mathrm{kg}$ of cobalt carbonate; $25,022 \mathrm{mg} / \mathrm{kg}$ of copper sulfate; $340 \mathrm{mg} / \mathrm{kg}$ of iodine; $100,715 \mathrm{mg} / \mathrm{kg}$ of iron sulfate; $49,906 \mathrm{mg} / \mathrm{kg}$ of manganese sulfate; $49,900 \mathrm{mg} / \mathrm{kg}$ of zinc sulfate; $1.0 \%$ mineral oil; rice hulls as carrier); $1.2 \%$ liquid molasses; $0.44 \%$ vitamin A; $0.13 \%$ vitamin $\mathrm{D}, 66 \mathrm{IU} / \mathrm{kg}$; and $0.017 \%$ vitamin $\mathrm{E}, 275,000 \mathrm{IU} / \mathrm{kg}$. 
daily during wk 6 before weaning. Calves were fed twice daily at 0500 and $1700 \mathrm{~h}$. From wk 7 to 12 (postweaning), calves were fed their respective pelleted starter. Amounts offered and refusals were measured once daily for each calf to determine intakes. Pelleted starters and water were offered ad libitum.

Daily fecal score were recorded as described by Stamey et al. (2012) following the scale of $1=$ firm, well-formed feces; 2 = soft, pudding-like; $3=$ runny, pancake batter; and $4=$ liquid and splatters. Calves were treated with electrolytes when diarrhea was found at a fecal score $\geq 3$ for more than $3 \mathrm{~d}$.

\section{Measurements and Sample Collection}

Milk replacers and samples of each pellet were taken weekly and kept frozen $\left(-20^{\circ} \mathrm{C}\right)$ for subsequent analyses. Equal portions from 4 consecutive weeks were composited to make monthly composites for nutrient analyses. Every week, an aliquot of pellet samples was dried for $24 \mathrm{~h}$ at $105^{\circ} \mathrm{C}$ for $\mathrm{DM}$ analysis to determine starter pellet DMI.

Calves were weighed during wk $0,2,4,6,8,10$, and 12 on 2 consecutive days during the experiment. At the same times, calves were measured for frame growth including hip height, hip width, heart girth, paunch girth, and body length. Body length was measured from the top point of withers to the end of the ischium (Hoffman, 1997). Calf BCS on a scale of 1 to 5 with 1 being emaciated and 5 being obese was observed by 3 independent individuals on the same schedule as growth measurements (Wildman et al., 1982).

During wk 12, fecal grab samples were taken to measure total-tract DM digestibility of DM, OM, CP, and fiber by the calves. Over $3 \mathrm{~d}$, fecal grab samples were collected at 0430, 0630, 1200, 1630, and $1800 \mathrm{~h}$ and kept frozen $\left(-20^{\circ} \mathrm{C}\right)$ until subsequent processing and analysis.

Blood samples were taken at the same time as BW and body measures for metabolite analyses. Blood samples were collected mid morning, approximately 3 $\mathrm{h}$ postfeeding, via venipuncture of a jugular vein into vacutainer tubes (Becton, Dickinson, and Company, Franklin Lakes, NJ) containing sodium fluoride (NaFl) for glucose analysis or potassium ethylene diamine tetra-acetic acid ( $\mathrm{K}_{2}$ EDTA) for all other analyses. Following blood collection, samples were immediately placed on ice and then brought within $3 \mathrm{~h}$ to the laboratory for processing. Blood collection tubes were centrifuged at $1,000 \times g$ for $20 \mathrm{~min}$ at $4^{\circ} \mathrm{C}(\mathrm{CR} 412$, Jouan Inc., Winchester, VA). Plasma or serum was transferred into polystyrene storage tubes and frozen at $-20^{\circ} \mathrm{C}$ until further analysis.

\section{Laboratory Analysis}

Fecal grab samples were composited on an equal wet weight basis for each calf at the end of trial. Individual feed ingredient samples, pelleted starter composites, and fecal composites were dried in duplicate for $48 \mathrm{~h}$ at $55^{\circ} \mathrm{C}$ in a Despatch oven (style V-23, Despatch Oven Co., Minneapolis, MN). Dried samples were ground to $2 \mathrm{~mm}$ particle size using a Wiley mill (model 3, Arthur H. Thomas Co., Philadelphia, PA), then ground further to $1 \mathrm{~mm}$ particle size with an ultracentrifuge mill (Brinkman Instruments Co., Westbury, NY). To correct analyses to $100 \%$ DM, 1-g aliquots of samples were dried for $3 \mathrm{~h}$ in a $105^{\circ} \mathrm{C}$ oven.

Ash content was analyzed by incinerating 1 -g samples for $8 \mathrm{~h}$ at $450^{\circ} \mathrm{C}$ in a muffle furnace (AOAC International, 2002; method 942.05). Organic matter was calculated as $\mathrm{OM}=(100-\%$ ash $)$. Milk replacer samples and pelleted starter samples were analyzed for nitrogen content by Dumas combustion analysis (AOAC International, 2002; method 968.06), on a Rapid N cube (Elementar Analysensysteme GmBH, Hanau, Germany). To find $\mathrm{CP}$ concentrations, feed sample nitrogen content was multiplied by 6.25 and MR nitrogen content was multiplied by 6.38. Neutral detergent fiber (Van Soest et al., 1991) and ADF (Robertson and Van Soest, 1981) were analyzed by using the Ankom 200 fiber analysis system (Ankom Technology Corp., Fairport, NY). Heat stable $\alpha$ amylase and sodium sulfite were used for NDF analysis. Feed samples were analyzed for ether extract (EE) content using diethyl ether (AOAC International, 2002; method 920.39) in an Ankom XT10 fat analysis system (Ankom Technology Corp.). Nonfiber carbohydrates were calculated as $\% \mathrm{NFC}=100-(\%$ ash $+\%$ $\mathrm{CP}+\% \mathrm{NDF}+\% \mathrm{EE})$ according to the NRC (2001).

Milk replacer and pelleted starter samples were further composited in 4-mo composites. Milk replacer was analyzed for lactose content using methods described by Biswas et al. (2011). Four-month composites of calf starter pellets and MR samples were sent to a commercial laboratory (Dairyland Laboratories Inc., Arcadia, WI) for additional analysis. Milk replacers were analyzed for fat, $\mathrm{Ca}, \mathrm{P}, \mathrm{Mg}, \mathrm{K}, \mathrm{S}, \mathrm{Na}$, and $\mathrm{Cl}$. Pelleted calf starters were analyzed for starch, Ca, P, Mg, K, $\mathrm{S}, \mathrm{Na}$, and $\mathrm{Cl}$. Milk replacer fat content was analyzed using Mojonnier methods (AOAC International, 2002; method 989.05). Mineral content, excluding chloride, was determined using inductively coupled plasma spectroscopy (AOAC International, 1995). Chloride content was determined using a direct reading chloride analyzer (Corning 926, Corning Inc., Corning, NY). Starch was analyzed using a modified procedure analyzing glucose using an YSI Biochemistry Analyzer (YSI Inc., Yellow Springs, OH; Bach Knudsen, 1997). 
For apparent total-tract digestibility calculations, acid detergent insoluble ash was used as an internal marker. The acid detergent insoluble ash content of feeds and feces was determine by analyzing samples for $\mathrm{ADF}$, as previously described, and ash content was determined by incinerating the Ankom bags for $8 \mathrm{~h}$ at $450^{\circ} \mathrm{C}$ in a muffle furnace. Calculations for digestibility were done as described by Merchen (1988).

Blood metabolites including glucose, BHB, triglyceride, and plasma urea nitrogen (PUN) were analyzed with commercially available enzymatic or colorimetric assay kits on a microplate spectrophotometer (Cary 50, Varian Inc., Walnut Creek, CA). Serum glucose was analyzed by glucose oxidase as described by Trinder (1969; Pointe Scientific Inc., Canton, MI). Concentration of BHB was analyzed by BHB dehydrogenase and diaphorase according to method described by McMurray et al. (1984; Pointe Scientific Inc.). Diacteyl monoxime was used to analyze PUN (procedure 0580, Stanbio Laboratory, Boerne, TX). Plasma triglyceride concentrations were analyzed using glycerol phosphate oxidase after hydrolysis by lipoprotein lipase, as described by Fossati and Lorenzo (1982; Pointe Scientific Inc.).

Plasma concentrations of IGF-I were determined in duplicate by RIA as described by Echternkamp et al. (1990) and Funston et al. (1995). To extract the insulin-like growth factor binding proteins (IGFBP) from the plasma, samples were incubated overnight with a ratio of 1:17 sample to acidified ethanol $(12.5 \% 2 \mathrm{~N}$ HCl:87.5\% absolute ethanol; Daughaday et al., 1980). Then, the extracted IGFBP was separated by centrifuging $\left(12,000 \times g\right.$ at $\left.4^{\circ} \mathrm{C}\right)$ the samples. An aliquot of supernatant was taken and neutralized with 0.855 $M$ Tris base. Samples were then incubated overnight again at $4^{\circ} \mathrm{C}$ and were again centrifuged at the same speed and temperature to remove any residual IGFBP. Inhibition curves of the neutralized extracted plasma (range 25-50 $\mu \mathrm{L}$ ) were parallel to standard curve. The radioiodinated antigen and standard used was recombinant human IGF-I (GF-050, Austral Biological, San Ramon, CA). Antisera AFP4892898 (National Hormone and Peptide Program, Harbor-UCLA Medical Center, Torrance, CA) was used to a dilution of 1:50,000. Intraassay coefficient of variation was $3.5 \%$, and interassay coefficient of variation was $8.8 \%$.

\section{Statistical Analysis}

R Statistical Software (R Core Team, 2015) was used for quantification of means and standard errors for nutrient analyses data. Calf intake, growth data, fecal consistency scores, and metabolic profile parameters were analyzed as a randomized complete block design with repeated measures using the MIXED procedures of SAS (Littell et al., 2008). Calves were assigned to 12 blocks based on birth date and sex. The model included treatment, week, sex, and interactions of these terms. Initial body size measurements and BW were included as covariates within the model. Repeated measures by week of the feeding period were done on intakes, BW, body measures, fecal consistency scores, and metabolites using calf (block) as the subject. Akaike's criterion was used to determine the most suitable covariance structure in repeated measures for each parameter. Covariance structures tested were compound symmetry, first-order autoregressive, Toeplitz, and unstructured. Compound symmetry was chosen at the covariance structure due to having the least absolute Akaike's values. For starter intake, total DMI, and fecal consistency scores means for each stage (preweaning and postweaning) were also tested with a model including treatment, stage, sex, and interactions of these terms. The slice command was used to determine the effects of treatments within an individual week or stage. Significant differences among treatments were declared at $P \leq 0.05$ and tendencies were declared at $0.05<P \leq 0.10$. Because treatment $\times$ sex interactions were limited, those results are not presented. To determine ADG for BW and change per day for body frame measurements, the difference was found between each data collection time point and the previous time point and then divided by the number of days in the time period [i.e., (wk $2-$ wk $0) / 14 \mathrm{~d}]$. Gain-to-feed ratio was calculated as the ratio of ADG of BW to total DMI for each treatment, which includes DMI of MR and pellets.

For analysis of data for apparent total-tract digestibility of nutrients, MIXED procedures of SAS were also used, but the model included only treatment with block included as a random variable. Significant differences among treatments were declared at $P \leq 0.05$ and tendencies were declared at $0.05<P \leq 0.10$.

\section{RESULTS}

\section{Nutrient Composition}

The nutrient composition of feed ingredients used to make starter pellets is presented in Table 2. The analyzed CP \% was greater in MSP than in SBM at 62.57 versus $50.12 \%$, respectively. The nutrient composition of SBM and MSP pelleted starters are presented in Table 3. The SBM and MSP pellets were formulated to obtain 20 and $23 \% \mathrm{CP}$, respectively, but actual content was slightly greater in both at 21.23 and $23.97 \%$. There was also a small difference in starch and NFC content between pellets, which was not anticipated based on individual feed nutrient composition. The MSP pellets had more sulfur compared with the SBM pellets due to 
Table 2. Nutrient composition of corn grain, wheat middlings, soybean meal (SBM), and microbially enhanced soy protein (MSP) used to make calf starter pellets

\begin{tabular}{|c|c|c|c|c|c|c|c|c|}
\hline \multirow[b]{2}{*}{ Item, $\%$ of DM } & \multicolumn{2}{|c|}{ Corn } & \multicolumn{2}{|c|}{ Wheat middlings } & \multicolumn{2}{|c|}{$\mathrm{SBM}$} & \multicolumn{2}{|c|}{ MSP } \\
\hline & Mean & $\mathrm{SE}$ & Mean & $\mathrm{SE}$ & Mean & SE & Mean & SE \\
\hline Ash & 1.72 & 0.04 & 5.71 & 0.09 & 7.07 & 0.04 & 7.81 & 0.07 \\
\hline $\mathrm{OM}$ & 98.27 & 0.36 & 94.29 & 0.09 & 92.92 & 0.09 & 92.20 & 0.07 \\
\hline $\mathrm{CP}$ & 9.76 & 0.36 & 18.98 & 0.18 & 50.12 & 0.13 & 62.57 & 1.81 \\
\hline $\mathrm{ADF}$ & 2.87 & 0.034 & 10.83 & 0.16 & 3.67 & 0.003 & 4.36 & 0.42 \\
\hline $\mathrm{NFC}^{1}$ & 75.55 & 0.41 & 35.12 & 0.50 & 34.85 & 0.09 & 43.92 & 0.27 \\
\hline Starch & 64.84 & - & 19.50 & - & - & - & - & - \\
\hline
\end{tabular}

${ }_{1} \% \mathrm{NFC}=100-(\%$ ash $+\% \mathrm{CP}+\% \mathrm{NDF}+\% \mathrm{EE})(\mathrm{NRC}, 2001)$.

the fungal processing method. The MSP product has added buffers to help alleviate any issues with the high sulfur content. Table 4 presents nutrient composition of MR. The CP \% of conventional MR and MR formulated for accelerated growth was 21.34 and $29.82 \%$, on a DM basis, respectively. Both MR were based on milk protein. The analyzed fat content of conventional MR and MR formulated for accelerated growth was 20.68 and $19.26 \%$ on a DM basis, respectively. The measured lactose content of conventional MR and MR formulated

Table 3. Nutrient composition for calf starter pellets containing soybean meal (SBM) or containing microbially enhanced soybean meal (MSP) fed to calves

\begin{tabular}{|c|c|c|c|c|}
\hline \multirow[b]{2}{*}{ Item $^{1}$} & \multicolumn{2}{|c|}{ SBM pellets } & \multicolumn{2}{|c|}{ MSP pellets } \\
\hline & Mean & $\mathrm{SE}$ & Mean & SE \\
\hline$\overline{\mathrm{DM}^{2}}$ & 89.0 & 0.06 & 88.20 & 0.05 \\
\hline $\mathrm{Ash}^{2}$ & 7.89 & 0.10 & 6.98 & 0.05 \\
\hline $\mathrm{OM}^{2}$ & 91.95 & 0.11 & 92.86 & 0.06 \\
\hline $\mathrm{CP}^{2}$ & 21.23 & 0.20 & 23.97 & 0.20 \\
\hline $\mathrm{ADF}^{2}$ & 5.94 & 0.15 & 6.17 & 0.20 \\
\hline $\mathrm{NDF}^{2}$ & 16.82 & 0.21 & 17.95 & 0.29 \\
\hline Ether extract $(\mathrm{EE})^{2}$ & 2.83 & 0.16 & 3.07 & 0.16 \\
\hline $\mathrm{NFC}^{2,3}$ & 51.23 & 0.39 & 48.03 & 0.35 \\
\hline $\mathrm{Starch}^{4}$ & 32.35 & 0.35 & 30.41 & 0.27 \\
\hline $\mathrm{Ca}^{4}$ & 1.00 & 0.05 & 0.85 & 0.02 \\
\hline $\mathrm{P}^{4}$ & 0.96 & 0.02 & 0.82 & 0.01 \\
\hline $\mathrm{Mg}^{4}$ & 0.34 & 0.01 & 0.32 & 0.01 \\
\hline $\mathrm{K}^{4}$ & 1.25 & 0.02 & 1.12 & 0.01 \\
\hline $\mathrm{S}^{4}$ & 0.34 & 0.01 & 0.59 & 0.01 \\
\hline $\mathrm{Na}^{4}$ & 0.49 & 0.02 & 0.32 & 0.01 \\
\hline $\mathrm{Cl}^{4}$ & 0.66 & 0.01 & 0.44 & 0.02 \\
\hline $\mathrm{ME},{ }^{5}$ Mcal $/ \mathrm{kg}$ & 3.13 & - & 3.17 & - \\
\hline $\mathrm{NE}_{\mathrm{G}},{ }^{5} \mathrm{Mcal} / \mathrm{kg}$ & 1.79 & - & 1.81 & - \\
\hline DCAD, $\mathrm{mEq} / 100 \mathrm{~g}$ & 13.37 & 0.90 & -7.16 & 0.71 \\
\hline
\end{tabular}

${ }_{1} \%$ of DM unless otherwise indicated.

${ }^{2}$ Analysis performed on monthly composites $(\mathrm{n}=8)$.

${ }^{3} \mathrm{NFC}=100-(\%$ ash $+\% \mathrm{CP}+\% \mathrm{NDF}+\% \mathrm{EE})(\mathrm{NRC}, 2001)$.

${ }^{4}$ Analysis performed on 4 -mo composites $(\mathrm{n}=2)$.

${ }^{5}$ Calculated by inputting nutrient composition into NRC (2001) software. for accelerated growth was 34.0 and $29.3 \%$ on a DM basis, respectively.

\section{Intakes}

Starter pellet DMI is shown in Figure 1. Mean DM, $\mathrm{CP}, \mathrm{EE}$, starch, lactose, and NDF intakes are presented in Table 5. Intakes of nutrients reflect the differences in the pelleted starters and MR on a DM basis and consumption of starter pellets. Total DMI, starch, and NDF intakes were greater $(P<0.05)$ for calves fed SBMA compared with calves fed MSPC with calves fed MSPA similar to both. The fat intakes tended to be greater $(P=0.06)$ for calves fed SBMA compared with calves fed MSPC with MSPA similar to both. The CP intake (Figure 2 and Table 5) was greater for calves fed MSPA and SBMA compared with MSPC, with treatment by week interactions. Lactose intake during the preweaning phase was greater $(P<0.01)$ for calves fed MSPC than MSPA and SBMA.

Table 4. Nutrient composition of conventional milk replacer and accelerated growth milk replacer fed to calves from 1 to 6 wk of age

\begin{tabular}{lrlrrr}
\hline & \multicolumn{2}{c}{ Conventional } & & \multicolumn{2}{c}{ Accelerated } \\
\cline { 2 - 3 } \cline { 5 - 6 } $\begin{array}{l}\text { Item, } \\
\text { of DM }\end{array}$ & Mean & SE & & Mean & SE \\
\hline $\mathrm{DM}^{1}$ & 96.77 & 0.22 & & 96.69 & 0.14 \\
$\mathrm{Ash}^{1}$ & 9.46 & 0.12 & & 9.47 & 0.16 \\
$\mathrm{OM}^{1}$ & 90.54 & 0.12 & & 90.53 & 0.16 \\
$\mathrm{CP}^{1}$ & 21.34 & 0.10 & & 29.82 & 0.13 \\
$\mathrm{Fat}^{2}$ & 20.68 & 0.16 & & 19.26 & 0.31 \\
$\mathrm{Lactose}^{2}$ & 34.00 & 0.28 & & 29.35 & 0.25 \\
$\mathrm{Ca}^{2}$ & 1.16 & 0.05 & & 0.93 & 0.08 \\
$\mathrm{P}^{2}$ & 0.74 & 0.03 & & 0.78 & 0.02 \\
$\mathrm{Mg}^{2}$ & 0.15 & 0.01 & & 0.16 & 0.01 \\
$\mathrm{~K}^{2}$ & 1.89 & 0.03 & & 2.13 & 0.08 \\
$\mathrm{~S}^{2}$ & 0.30 & 0.00 & & 0.54 & 0.02 \\
$\mathrm{Na}^{2}$ & 1.04 & 0.06 & & 1.26 & 0.01 \\
$\mathrm{Cl}^{2}$ & 0.43 & 0.01 & 0.49 & 0.02 \\
\hline
\end{tabular}

${ }^{1}$ Analysis performed on monthly composites $(\mathrm{n}=8)$.

${ }^{2}$ Analysis performed on 4-mo composites $(\mathrm{n}=2)$. 


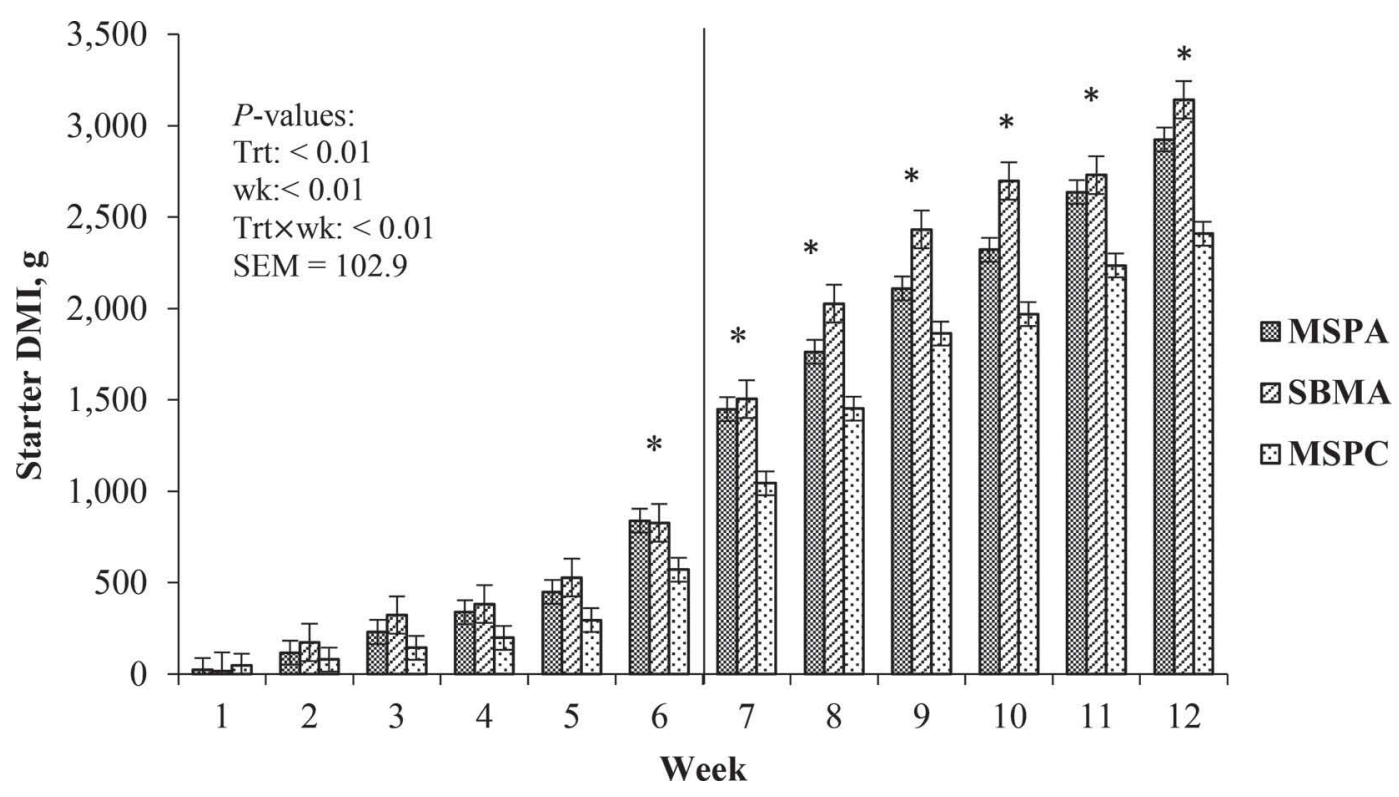

Figure 1. Weekly averages of starter DMI for calves fed pellets with microbially enhanced soy protein and accelerated growth milk replacer (MSPA), pellets with soybean meal and accelerated growth milk replacer (SBMA), or pellets with microbially enhanced soy protein and conventional milk replacer (MSPC). ${ }^{*}$ indicates values differ by $P<0.05$. Trt $=$ treatment. Error bars represent SEM.

\section{BW, ADG, and Gain:Feed}

Table 6 shows mean BW, ADG, feed intakes, and G:F results. Overall, mean BW (Figure 3) were greater $(P=0.02)$ for calves on the MSPA treatment compared with calves fed MSPC with SBMA in the middle and similar to both. Body weight had a treatment by week interaction $(P<0.01)$. The 3 treatments were similar in the first 6 wk of the study, but after weaning differences in BW of MSPC-fed calves compared with the MSPA and SBMA fed calves became more pronounced. Overall pelleted starter intake (Table 6 and Figure 1) was greatest $(P<0.01)$ for calves fed SBMA and least for calves fed MSPC, with calves fed MSPA intermediate. During the preweaning stage, starter intake for calves fed MSPA was similar to both of the other treatments, but differences were found between all treatments during the postweaning stage. Milk replacer intake was similar among all treatments due to similar feeding rates. Because of similar MR intakes, total DMI and starter pellet DMI intakes had the same differences among treatments. Dry matter intake as a $\%$ of BW (Table 6$)$ was similar $(P=0.81)$ among treatments, but treatment by stage and treatment by week interactions were found. Postweaning, calves fed SBMA showed a tendency $(P=0.08)$ to have greater DMI as a $\%$ of BW compared with the other treatments. Average daily gain had a treatment by week interaction $(P=$

Table 5. Nutrient intakes for Holstein calves fed pellets with microbially enhanced soy protein and accelerated growth milk replacer (MSPA), pellets with soybean meal and accelerated growth milk replacer (SBMA), or microbially enhanced soy protein and conventional milk replacer (MSPC)

\begin{tabular}{|c|c|c|c|c|c|c|c|}
\hline Item & \multicolumn{3}{|c|}{ Treatment } & SEM & \multicolumn{3}{|c|}{$P$-value ${ }^{1}$} \\
\hline Total DMI, g/d & 1,645 & 1,777 & 1,403 & 93.3 & $<0.01$ & $<0.01$ & $<0.01$ \\
\hline Fat intake, ${ }^{2} \mathrm{~g} / \mathrm{d}$ & 109.2 & 115.4 & 106.9 & 2.80 & 0.06 & $<0.01$ & $<0.01$ \\
\hline Starch intake, g/d & 385.2 & 452.5 & 312.0 & 28.94 & $<0.01$ & $<0.01$ & $<0.01$ \\
\hline Lactose intake, ${ }^{3} \mathrm{~g} / \mathrm{d}$ & 222.1 & 222.2 & 256.2 & 1.49 & $<0.01$ & $<0.01$ & 0.01 \\
\hline
\end{tabular}

${ }^{1} P$-values for effects of treatment (Trt), week (wk), and the treatment $\times$ week interaction (Trt $\times$ wk).

${ }^{2}$ Fat intake was determined by ether extract.

${ }^{3}$ Calves were weaned from milk replacer at the end of wk 6 . 
0.03). Gain-to-feed ratio (Table 6; Figure 4) was similar among treatments, although there was a treatment by week interaction $(P<0.01)$ and variation among treatments and within treatments week to week.

\section{Body Frame Growth}

Hip height and heart girth (Table 7$)$ were greater $(P$ $<0.05)$ for calves fed MSPA than calves fed MSPC, with calves fed SBMA similar to both. Body length was shorter for calves fed MSPC compared with calves fed MSPA or SBMA. Hip width was similar $(P=0.13)$ among treatments. Paunch girth was greater $(P=$ 0.02 ) in calves fed SBMA compared with MSPC with calves fed MSPA similar to both. Overall BCS were similar $(P=0.17)$ among treatments, but a treatment by week interaction $(P<0.01)$ was found. However, average changes per day or 2-wk intervals for all frame measurements were similar among treatments.

\section{Fecal Consistency}

Fecal consistency scores and frequency of scores $\geq 3$ (Table 8) were similar among treatments. Calves fed MSPA averaged fecal consistency scores of 1.17 and SBMA and MSPC had fecal consistency scores of 1.15 and did not show significant differences $(P=0.95)$ among treatments. Fecal consistency scores were greater $(P<0.01)$ in the preweaning stage compare with the postweaning stage. Frequencies of scouring were similar among treatment $(P=0.14)$ and low for all treatments.

\section{Metabolic Profile}

Table 9 presents overall means of blood metabolite concentrations for calves fed MSPA, SBMA, and MSPC. Treatment effects and treatment by week interactions were found for blood metabolites including PUN, glucose, and BHB. Plasma urea nitrogen concentrations (Figure 5) were greater $(P<0.01)$ in calves fed MSPA than those fed MSPC with SBMA similar to both. Mean serum concentrations of glucose were similar $(P=0.50)$ among treatments. The concentrations of plasma triglycerides were $(P=0.01)$ greater in calves fed MSPC compared with other treatments. Results showed a lesser $(P<0.01)$ plasma concentration of IGF-1 (Figure 6) in MSPC compared with SBMA-fed calves with MSPA intermediate. Plasma concentration of BHB (Figure 7) demonstrated a treatment by week interaction $(P<0.01)$ with more variation among treatments in the postweaning phase.

\section{Apparent Total-Tract Digestion}

Apparent total-tract digestion of nutrients is presented in Table 10. Apparent total-tract DM digestion was numerically greater in calves fed MSPC compared with other treatments. Crude protein digestion was

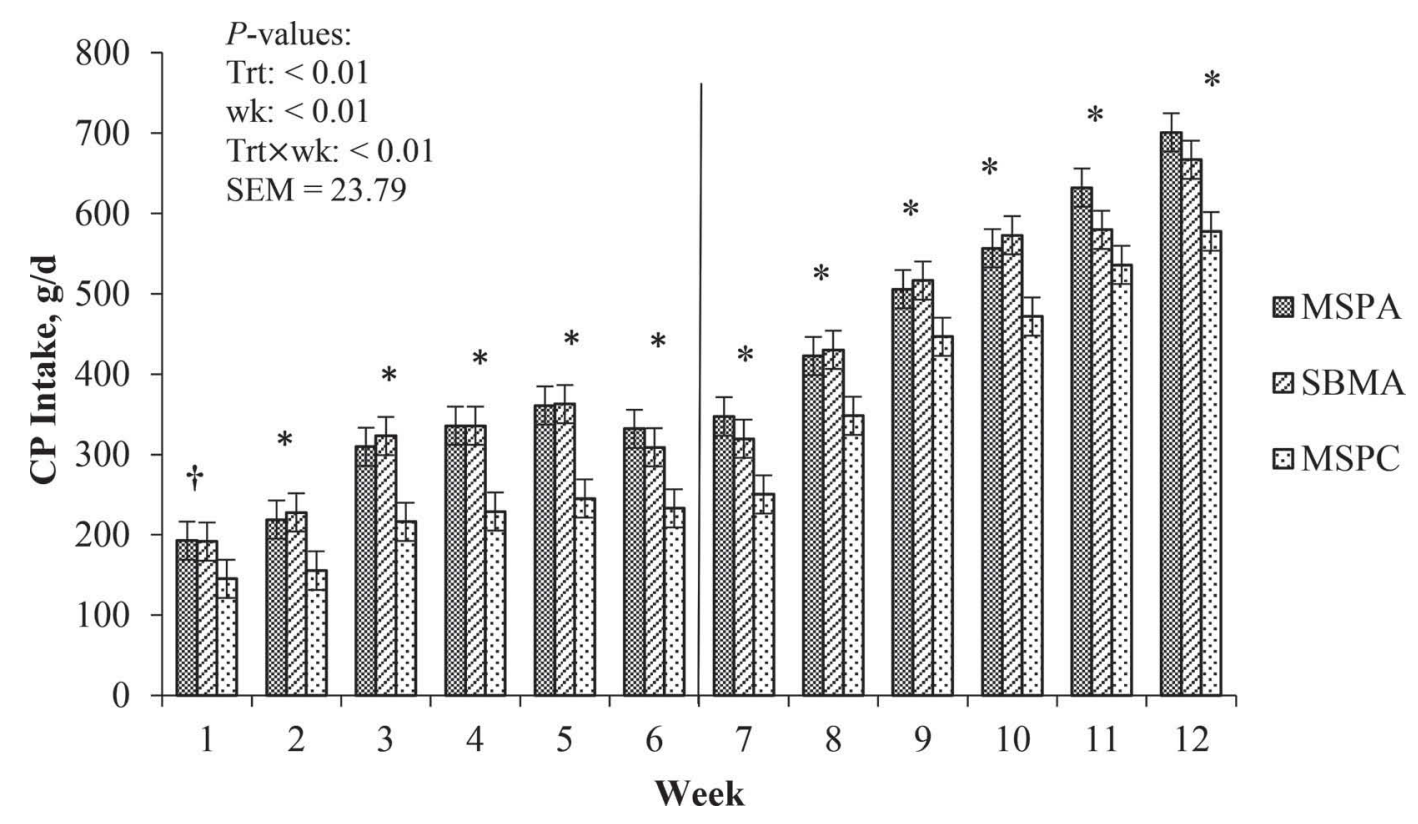

Figure 2. Weekly averages of CP intake for calves fed pellets with microbially enhanced soy protein and accelerated growth milk replacer (MSPA), pellets with soybean meal and accelerated growth milk replacer (SBMA), or pellets with microbially enhanced soy protein and conventional milk replacer (MSPC). ${ }^{*}$ indicates values differ by $P<0.05$, and $\dagger$ indicates values differ by $P<0.10$. Trt $=$ treatment. Error bars represent SEM. 


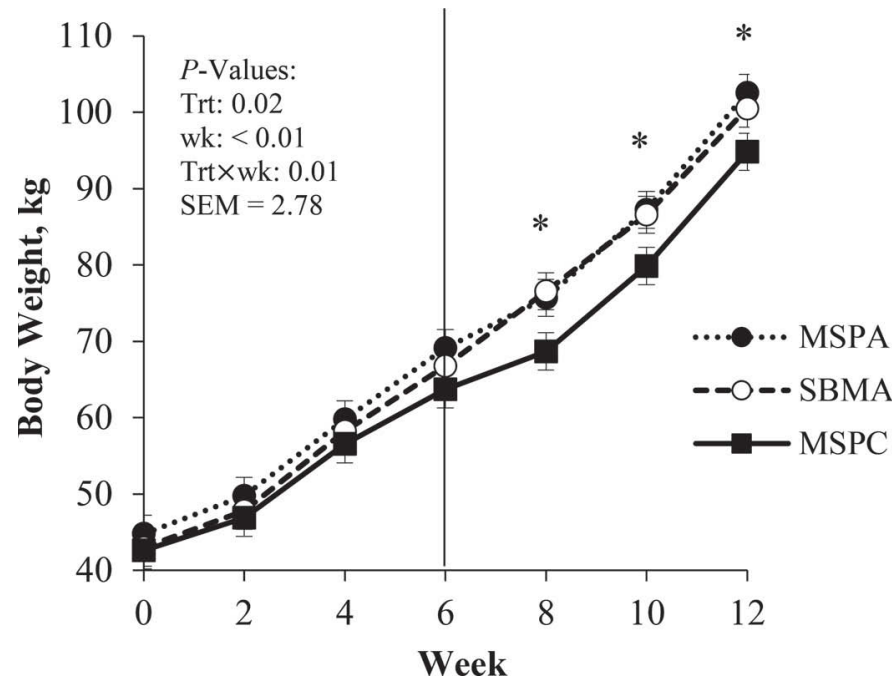

Figure 3. Body weights for calves fed pellets with microbially enhanced soy protein and accelerated growth milk replacer (MSPA), pellets with soybean meal and accelerated growth milk replacer (SBMA), or pellets with microbially enhanced soy protein and conventional milk replacer $(\mathrm{MSPC}) .{ }^{*}$ indicates values differ by $P<0.05$. Trt $=$ treatment. Error bars represent SEM.

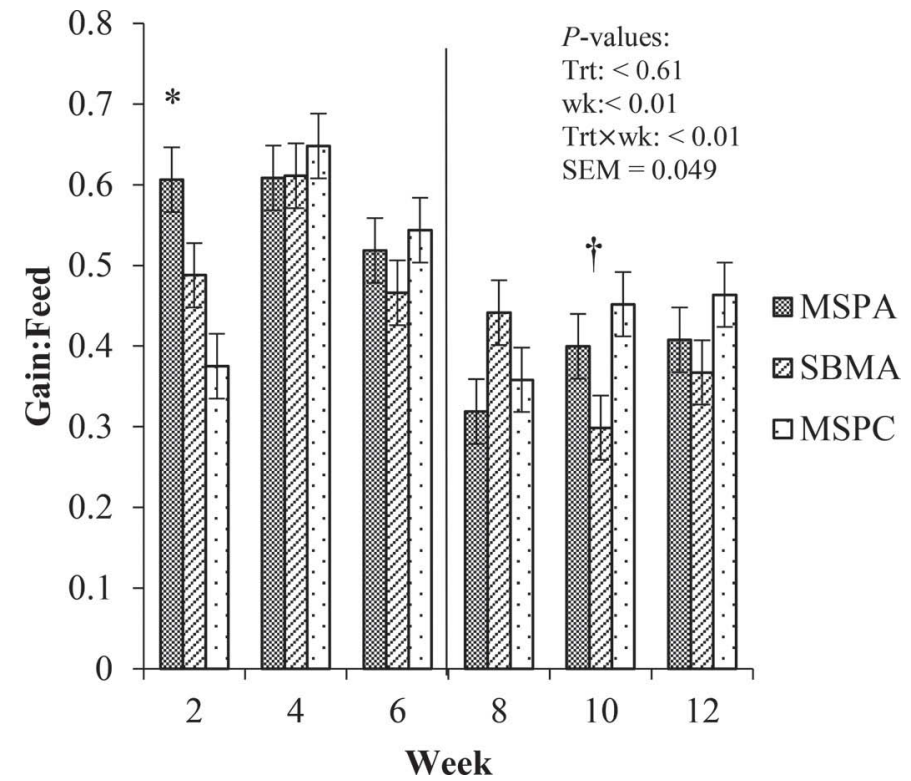

Figure 4. Gain:feed for calves fed pellets with microbially enhanced soy protein and accelerated growth milk replacer (MSPA), pellets with soybean meal and accelerated growth milk replacer (SBMA), or pellets with microbially enhanced soy protein and conventional milk replacer (MSPC). * indicates values differ by $P<0.05$, and $\dagger$ indicates values differ by $P<0.10$. Trt $=$ treatment. Error bars represent SEM.

Table 6. Body weight, ADG, DMI, and gain-to-feed ratios for Holstein calves fed pellets with microbially enhanced soy protein and accelerated growth milk replacer (MSPA), pellets with soybean meal and accelerated growth milk replacer (SBMA), or microbially enhanced soy protein and conventional milk replacer (MSPC)

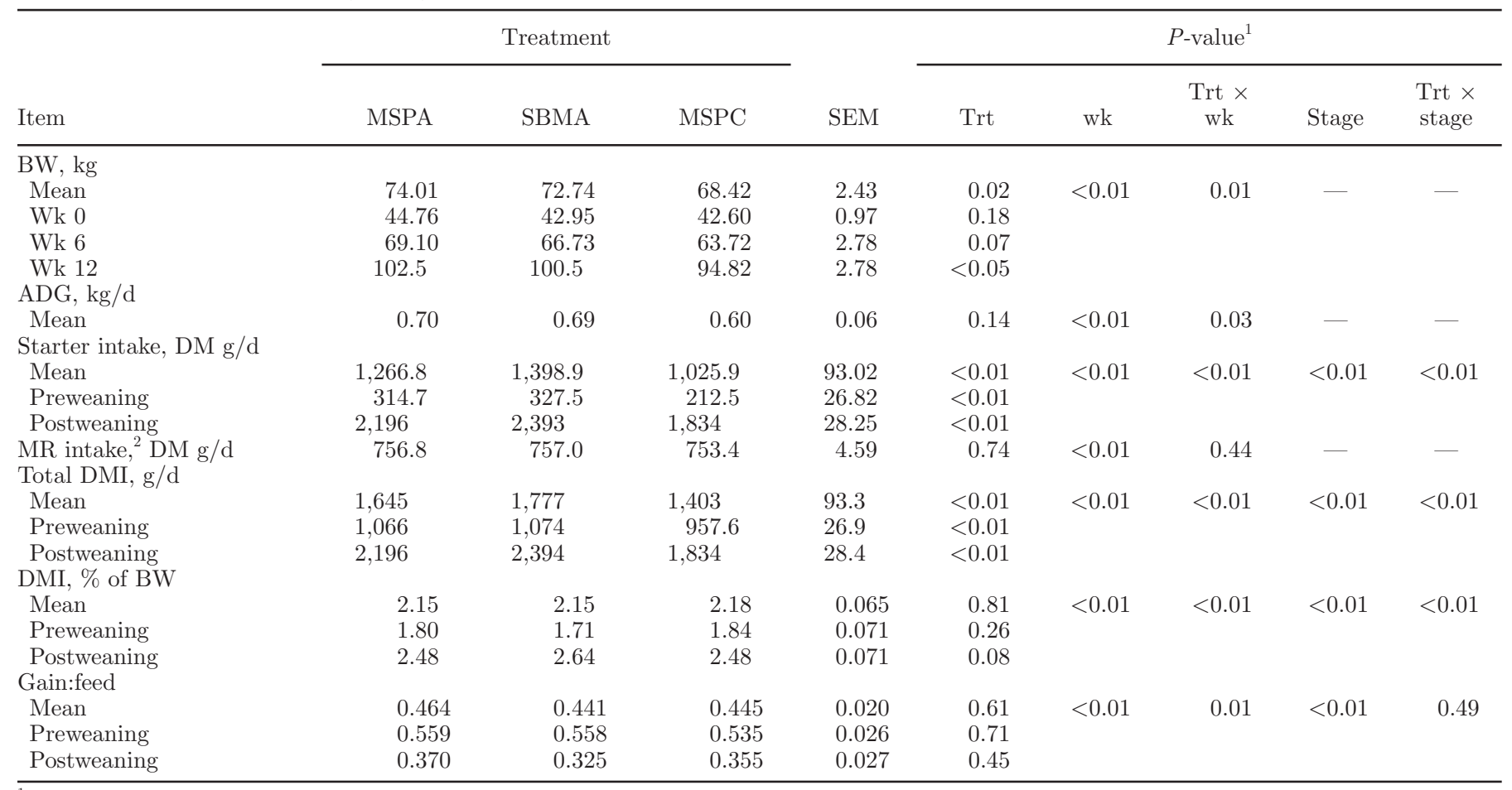

${ }^{1} P$-values for effects of treatment (Trt), week (wk), treatment $\times$ week interaction (Trt $\times$ wk), stage (preweaning vs. postweaning), and treatment $\times$ stage interaction $($ Trt $\times$ stage).

${ }^{2}$ Calves were weaned off milk replacer $(\mathrm{MR})$ at the end of wk 6. 
greater $(P<0.05)$ in the MSPC-fed calves compared with SBMA-fed calves, with MSPA-fed calves demonstrating intermediate digestion of CP. Acid detergent fiber digestion was increased $(P<0.01)$ in calves fed the MSPC diet compared with SBMA. However, NDF digestion was similar $(P=0.25)$ among treatments.

\section{DISCUSSION}

\section{Nutrient Composition}

Differences in total CP content of the pellets was anticipated because of the CP differences in the MSP and SBM ingredients. Part of our objective was to determine if the increased CP from the MSP benefited the calves. Increased provision of $\mathrm{CP}$ from starter during the weaning period is thought to support lean tissue growth (Stamey et al., 2012). Greater CP intake and starter pellet intake may potentially increase rumen development and BW gain during the weaning period. Furthermore, Feng et al. (2007) showed growthpromoting effects in piglets when fermented SBM was substituted for SBM, due to the greater concentrations of essential nutrients such as AA and vitamins, and the reduction of some anti-nutritional factors in fermented SBM. Therefore, it was speculated that the greater CP

Table 7. Frame growth measurements and BCS for Holstein calves fed pellets with microbially enhanced soy protein and accelerated growth milk replacer (MSPA), pellets with soybean meal and accelerated growth milk replacer (SBMA), or pellets with microbially enhanced soy protein and conventional milk replacer (MSPC)

\begin{tabular}{|c|c|c|c|c|c|c|c|}
\hline \multirow[b]{2}{*}{ Item } & \multicolumn{3}{|c|}{ Treatment } & \multirow[b]{2}{*}{ SEM } & \multicolumn{3}{|c|}{$P$-value ${ }^{1}$} \\
\hline & MSPA & SBMA & MSPC & & Trt & wk & Trt $\times$ wk \\
\hline \multicolumn{8}{|l|}{ Hip height, cm } \\
\hline Mean & 93.1 & 93.1 & 91.1 & 0.88 & 0.02 & \multirow[t]{4}{*}{$<0.01$} & \multirow[t]{4}{*}{0.38} \\
\hline Wk 0 & 83.2 & 82.8 & 81.4 & 0.73 & 0.16 & & \\
\hline $\mathrm{Wk} 6^{2}$ & 92.7 & 92.2 & 91.1 & 1.07 & 0.20 & & \\
\hline Wk 12 & 99.5 & 100.2 & 97.2 & 1.07 & 0.01 & & \\
\hline Change, $\mathrm{cm} / \mathrm{d}$ & 0.196 & 0.220 & 0.182 & 0.020 & 0.29 & $<0.01$ & 0.06 \\
\hline Change, $\mathrm{cm} / 2 \mathrm{wk}$ & 2.74 & 3.07 & 2.55 & 0.289 & 0.29 & $<0.01$ & 0.06 \\
\hline \multicolumn{8}{|l|}{ Heart girth, $\mathrm{cm}$} \\
\hline Mean & 92.9 & 92.8 & 90.3 & 1.04 & $<0.01$ & \multirow[t]{4}{*}{$<0.01$} & \multirow[t]{4}{*}{$<0.01$} \\
\hline Wk 0 & 76.9 & 76.1 & 75.7 & 0.69 & 0.49 & & \\
\hline $\mathrm{Wk} 6^{2}$ & 91.7 & 91.2 & 89.2 & 1.27 & 0.05 & & \\
\hline Wk 12 & 103.7 & 103.0 & 100.5 & 1.27 & $<0.01$ & & \\
\hline Change, $\mathrm{cm} / \mathrm{d}$ & 0.317 & 0.317 & 0.293 & 0.024 & 0.33 & $<0.01$ & $<0.01$ \\
\hline Change, $\mathrm{cm} / 2 \mathrm{wk}$ & 4.45 & 4.66 & 4.11 & 0.374 & 0.33 & $<0.01$ & $<0.01$ \\
\hline \multicolumn{8}{|l|}{ Paunch girth, cm } \\
\hline Mean & 98.3 & 110.2 & 96.2 & 1.53 & 0.02 & \multirow[t]{4}{*}{$<0.01$} & \multirow[t]{4}{*}{$<0.01$} \\
\hline Wk 0 & 76.6 & 74.9 & 75.5 & 0.74 & 0.20 & & \\
\hline $\mathrm{Wk} 6^{2}$ & 98.0 & 101.1 & 93.4 & 2.00 & $<0.01$ & & \\
\hline Wk 12 & 115.8 & 116.9 & 111.5 & 2.00 & $<0.01$ & & \\
\hline Change, $\mathrm{cm} / \mathrm{d}$ & 0.469 & 0.509 & 0.432 & 0.038 & 0.19 & $<0.01$ & 0.01 \\
\hline Change, $\mathrm{cm} / 2 \mathrm{wk}$ & 6.59 & 7.12 & 6.04 & 0.540 & 0.19 & $<0.01$ & 0.01 \\
\hline \multicolumn{8}{|l|}{ Body length, cm } \\
\hline Mean & 73.9 & 74.0 & 72.6 & 0.63 & 0.03 & \multirow[t]{4}{*}{$<0.01$} & \multirow[t]{4}{*}{0.80} \\
\hline Wk 0 & 64.0 & 63.2 & 62.7 & 0.62 & 0.22 & & \\
\hline $\mathrm{Wk} 6^{2}$ & 72.6 & 71.8 & 71.7 & 1.07 & 0.57 & & \\
\hline Wk 12 & 82.0 & 82.9 & 80.1 & 1.07 & 0.03 & & \\
\hline Change, $\mathrm{cm} / \mathrm{d}$ & 0.215 & 0.236 & 0.205 & 0.022 & 0.48 & $<0.01$ & 0.52 \\
\hline Change, $\mathrm{cm} / 2 \mathrm{wk}$ & 3.00 & 3.30 & 2.87 & 0.307 & 0.48 & $<0.01$ & 0.52 \\
\hline \multicolumn{8}{|l|}{ Hip width, cm } \\
\hline Mean & 20.55 & 19.98 & 19.67 & 0.51 & 0.13 & \multirow[t]{4}{*}{$<0.01$} & \multirow[t]{4}{*}{0.41} \\
\hline $\mathrm{Wk} 0$ & 13.85 & 14.66 & 14.13 & 1.11 & 0.86 & & \\
\hline $\mathrm{Wk} 6^{2}$ & 20.30 & 19.66 & 19.22 & 0.62 & 0.11 & & \\
\hline Wk 12 & 23.29 & 22.61 & 22.24 & 0.62 & 0.12 & & \\
\hline Change, $\mathrm{cm} / \mathrm{d}$ & 0.117 & 0.084 & 0.100 & 0.030 & 0.60 & $<0.01$ & 0.35 \\
\hline Change, $\mathrm{cm} / 2$ wk & 1.63 & 1.17 & 1.39 & 0.424 & 0.60 & $<0.01$ & 0.35 \\
\hline \multicolumn{8}{|l|}{$\mathrm{BCS}^{3}$} \\
\hline Mean & 2.64 & 2.53 & 2.57 & 0.058 & 0.17 & \multirow[t]{4}{*}{$<0.01$} & \multirow[t]{4}{*}{$<0.01$} \\
\hline Wk 0 & 2.08 & 2.05 & 2.07 & 0.04 & 0.73 & & \\
\hline $\mathrm{Wk} 6^{2}$ & 2.60 & 2.61 & 2.54 & 0.07 & 0.54 & & \\
\hline Wk 12 & 2.93 & 2.84 & 2.85 & 0.07 & 0.29 & & \\
\hline
\end{tabular}

${ }^{1} P$-values for effects of treatment $($ Trt $)$, week $(\mathrm{wk})$, and treatment $\times$ week interaction $($ Trt $\times$ wk $)$.

${ }^{2}$ Calves were weaned off milk replacer at the end of wk 6 .

${ }^{3}$ Scale of 1 to 5 with 1 being emaciated and 5 being obese. 
Table 8. Fecal scores for Holstein calves fed pellets with microbially enhanced soy protein and accelerated growth milk replacer (MSPA), pellets with soybean meal and accelerated growth milk replacer (SBMA), or pellets with microbially enhanced soy protein and conventional milk replacer (MSPC)

\begin{tabular}{|c|c|c|c|c|c|c|c|c|c|}
\hline Item & \multicolumn{3}{|c|}{ Treatment } & SEM & \multicolumn{5}{|c|}{$P$-value ${ }^{1}$} \\
\hline \multicolumn{10}{|l|}{$\overline{\text { Fecal score }^{2}}$} \\
\hline Preweaning & 1.3 & 1.3 & 1.3 & 0.24 & 0.48 & & & & \\
\hline Postweaning & 1.0 & 1.0 & 1.0 & 0.05 & 0.95 & & & & \\
\hline Scouring frequency, ${ }^{3} \%$ of calves/d & 2.92 & 3.50 & 1.99 & 0.832 & 0.14 & $<0.01$ & 0.01 & - & - \\
\hline
\end{tabular}

${ }^{1} P$-values for effects of treatment (Trt), week (wk), treatment $\times$ week interaction (Trt $\times$ wk), stage (preweaning vs. postweaning), and the treatment $\times$ stage interaction $($ Trt $\times$ Stage).

${ }^{2}$ Scale of 1 to 4 with 1 being firm and 4 being watery.

${ }^{3}$ Percentage of days that fecal consistency was $\geq 3$.

Table 9. Blood metabolite concentrations for Holstein calves fed pellets with microbially enhanced soy protein and accelerated growth milk replacer (MSPA), pellets with soybean meal and accelerated growth milk replacer (SBMA), or pellets with microbially enhanced soy protein and conventional milk replacer (MSPC)

\begin{tabular}{|c|c|c|c|c|c|c|c|}
\hline \multirow[b]{2}{*}{ Item } & \multicolumn{3}{|c|}{ Treatment } & \multirow[b]{2}{*}{ SEM } & \multicolumn{3}{|c|}{$P$-value ${ }^{1}$} \\
\hline & MSPA & SBMA & MSPC & & Trt & wk & Trt $\times$ wk \\
\hline $\mathrm{PUN},{ }^{2} \mathrm{mg} / \mathrm{dL}$ & 15.57 & 14.20 & 12.77 & 0.35 & $<0.01$ & $<0.01$ & $<0.01$ \\
\hline $\mathrm{BHB},{ }^{4} \mathrm{mg} / \mathrm{dL}$ & 34.52 & 35.62 & 31.79 & 1.27 & 0.02 & $<0.01$ & $<0.01$ \\
\hline Triglycerides, mg/dL & 25.22 & 24.83 & 28.79 & 1.08 & $<0.01$ & $<0.01$ & 0.39 \\
\hline $\mathrm{IGF}-1, \mathrm{ng} / \mathrm{mL}$ & 63.77 & 73.38 & 60.48 & 3.04 & $<0.01$ & $<0.01$ & 0.35 \\
\hline
\end{tabular}

${ }^{1} P$-values for effects of treatment $(\mathrm{Trt})$, week $(\mathrm{wk})$, and the treatment $\times$ week interaction $($ Trt $\times$ wk).

${ }^{2}$ Plasma urea nitrogen.

${ }^{3}$ Serum glucose.

${ }^{4}$ Plasma BHB.

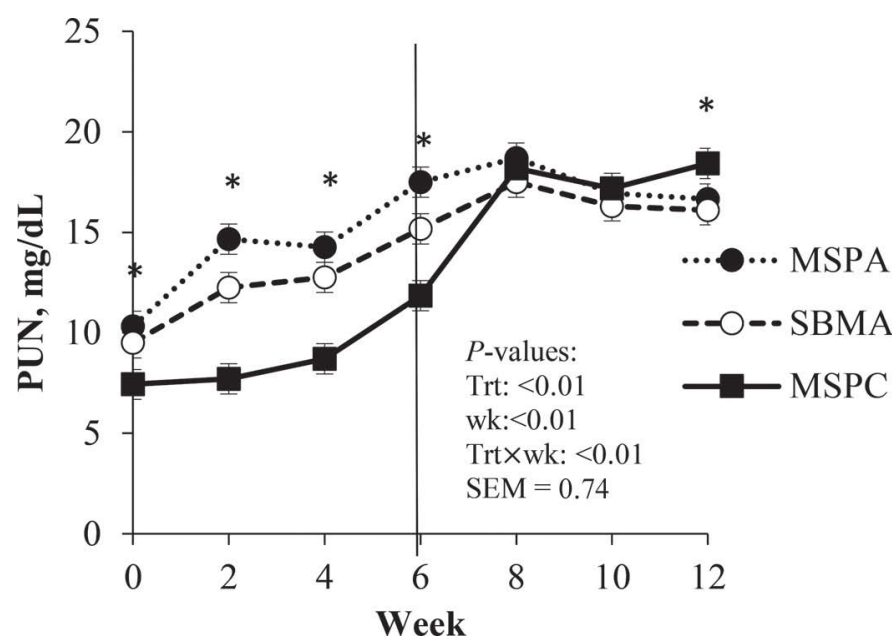

Figure 5. Plasma urea nitrogen (PUN) concentrations for calves fed pellets with microbially enhanced soy protein and accelerated growth milk replacer (MSPA), pellets with soybean meal and accelerated growth milk replacer (SBMA), or pellets with microbially enhanced soy protein and conventional milk replacer (MSPC). * indicates values differ by $P<0.05$. Trt $=$ treatment. Error bars represent SEM.

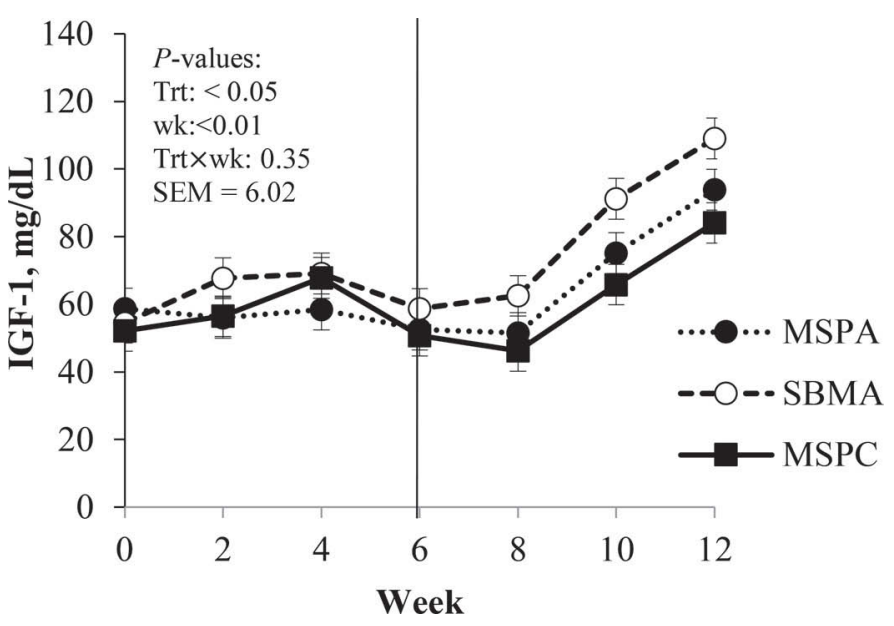

Figure 6. Concentrations of plasma IGF-1 for calves fed pellets with microbially enhanced soy protein and accelerated growth milk replacer (MSPA), pellets with soybean meal and accelerated growth milk replacer (SBMA), or pellets with microbially enhanced soy protein and conventional milk replacer $(\mathrm{MSPC})$. Trt $=$ treatment. Error bars represent SEM. 
Table 10. Week 12 apparent total-tract digestibility of nutrients for calves fed pellets with microbially enhanced soy protein and accelerated growth milk replacer (MSPA), pellets with soybean meal and accelerated growth milk replacer (SBMA), or microbially enhanced soy protein and conventional milk replacer (MSPC)

\begin{tabular}{|c|c|c|c|c|c|}
\hline \multirow[b]{2}{*}{ Digestibility, \% } & \multicolumn{3}{|c|}{ Treatment } & \multirow[b]{2}{*}{ SEM } & \multirow[b]{2}{*}{$P$-value } \\
\hline & MSPA & SBMA & MSPC & & \\
\hline DM & 81.0 & 80.3 & 84.8 & 1.58 & 0.10 \\
\hline CP & 86.4 & 85.1 & 89.7 & 1.37 & $<0.05$ \\
\hline $\mathrm{ADF}$ & 38.5 & 27.9 & 49.4 & 4.18 & $<0.01$ \\
\hline $\mathrm{NDF}$ & 54.8 & 58.1 & 63.1 & 3.61 & 0.25 \\
\hline
\end{tabular}

content in the MSP starter pellets would be beneficial for the calves on the current study.

\section{Intakes and Growth Performance}

Increased DMI through preweaning is important to maintain ADG into the postweaning period (Stamey et al., 2012). However, in the study the treatments fed MSP had similar or less DMI compared with the SBMA treatment. The greater CP content of the MSP pellets may have caused lesser intakes. Cowles et al. (2006) and Hill et al. (2006) showed that increased MR intakes with high protein decreased starter consumption during the preweaning period. Providing greater amount of protein from starter may maintain BW, even though calves had less starter intake or total DMI, because CP intake quantity was maintained.

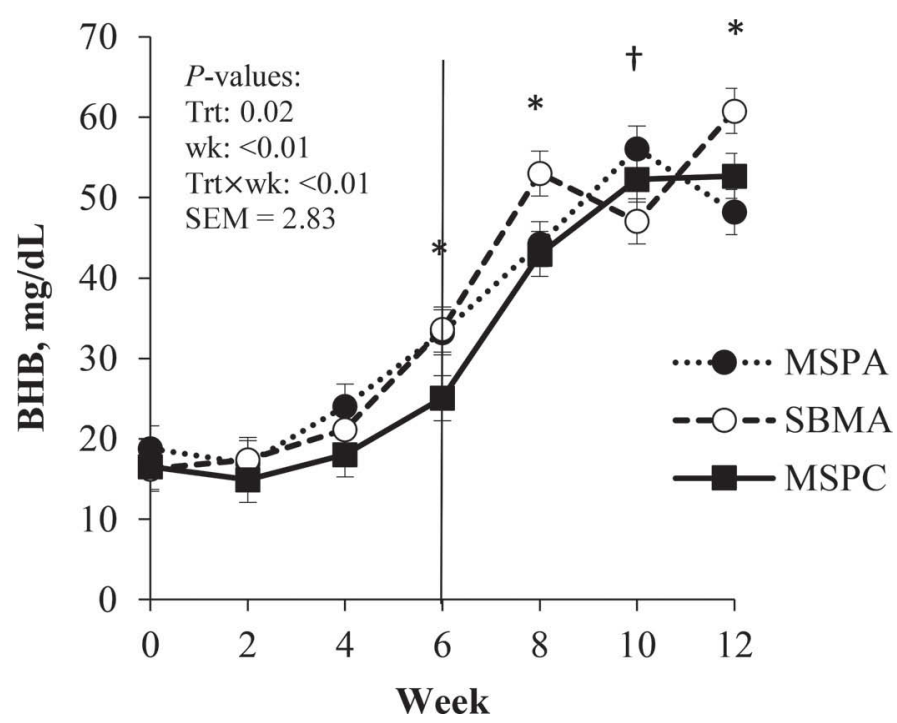

Figure 7. Concentrations of plasma BHB for calves fed pellets with microbially enhanced soy protein and accelerated growth milk replacer (MSPA), pellets with soybean meal and accelerated growth milk replacer (SBMA), or pellets with microbially enhanced soy protein and conventional milk replacer (MSPC). ${ }^{*}$ indicates values differ by $P<$ 0.05 , and $\dagger$ indicates values differ by $P<0.10$. Trt $=$ treatment. Error bars represent SEM.
The calves fed MSPC had lesser starter intake during the preweaning period and throughout, which was unexpected. This finding may be because consumption of starter in first 2 to $3 \mathrm{wk}$ was very low and calves mostly depended on MR during this period. Therefore, conventional MR-fed calves may have more limited nutrient intakes, especially $\mathrm{CP}$, for development and slightly reduced gains and BW. Consequently, when DMI was determined as a \% of BW, treatments had similar intakes during the preweaning period and only a tendency for a difference in the postweaning period.

Feeding SBM has been shown to reduce microbial protein synthesis in the developing rumen (Quigley et al., 1985). In addition, Vazquez-Anon et al. (1993) proved degradation of SBM in the rumen is lower at wk 2 postweaning calves than older calves at wk 4 to 8 postweaning. This might be another factor in why there was increased DMI for the calves fed SBMA, whereas calves fed MSP might have greater CP degradation in the rumen resulting less stimulation for DMI. We are unsure why calves fed MSPC had less DMI and pellet intake, especially in the postweaning period. As mentioned, it is speculated that this is a carryover effect of receiving fewer nutrients in the conventional MR and a slight lag in BW, as DMI as \% of BW was similar between MSPA- and MSPC-fed calves throughout the study. Gain-to-feed ratio varied week to week both within and among treatments. The MSP pellets appear to improve feed efficiency during more of the study duration. This could be because of the increased CP content in the pellets (Stamey et al., 2012), the increased digestibility of the CP from MSP compared with SBM (Sindelar, 2014), or from the effects of prebiotic compounds left from the fungal processing (Lesmeister et al., 2004; Bruce et al., 2015).

Small differences were found in frame sizes among treatments, but most importantly the average daily changes for the majority of measurements taken were not different among treatments, indicating the rates of frame growth were maintained across treatments. Paunch girth is related to digestive system development, intakes, and gut fill. In this study, paunch girth 
had similar patterns among treatments, especially in the postweaning period.

\section{Fecal Consistency}

All calves were healthy, making it difficult to detect treatment effects on fecal consistency and scouring frequency. Some leftover compounds of fungi such as mannan oligosaccharides and fructooligosaccharides would have potential to reduce diarrhea (Bruce et al., 2015). Fructooligosaccharide inclusion in human diets appears to result in fecal bulkiness (Van Loo et al., 1999). Increasing energy and protein intake of calves resulted in greater fecal scores and more days of diarrhea in other research (Brown et al., 2005). However, in this study calves did not have greater fecal consistency scores in MSP diets despite high CP intake.

\section{Metabolic Profile}

Most changes in metabolic profile are related to differences in nutrient intakes among treatments. Similar concentrations of glucose over the treatments indicate that calves were similar in energy status across diets. The concentration of PUN is associated with the protein intake, quality of protein, and development of ruminal fermentation (Quigley and Bernard, 1992). As a digestive system matures, PUN concentration increased more than in newborn calves (Kitchenham et al., 1975). In this study, total protein intake was greater in MSPA-fed calves than MSPC-fed calves and resulted in greater PUN concentration. It was also observed that concentration of PUN increased with consumption of starter intake and availability of protein from the starter. Greater consumption of starter had been shown to increase PUN concentration as calves age (Kitchenham et al., 1975). Because the young calf digestive system is not fully functional, they are not as capable at converting CP to microbial protein (Davis and Drackley, 1998) and therefore PUN concentrations may increase with increased CP intake.

The concentration of BHB is associated with utilization of body fat for energy in transition cows and also associated with butyric acid production. Butyric acid is a stimulatory factor for rumen epithelial development in young calves (Tamate et al., 1962). As calves have limited body fat for mobilization, the majority of circulating BHB is likely coming from rumen fermentation. During the experimental period, BHB increased over time at the same rate across treatments and increased after weaning. Concentration of $\mathrm{BHB}$ was greater in MSPA- and SBMA-fed calves compared with MSPC during a large portion of the postweaning phase, which mostly related to DMI and intake of carbohydrates as substrates for rumen fermentation. Triglyceride differences were due to differences in fat consumption from the 2 different MR.

The key metabolic regulator for growing animals is IGF-1, as it encourages nutrient uptake and cellular growth (Vacher et al., 1995; Odle et al., 1996). In addition, it may enhance development of the neonatal digestive system and may affect or interact with several other growth factors (Vacher et al., 1995). As weight gain increases, plasma concentration of IGF-1 also increases (Smith and Sheffield, 2002). However, in this study calves had less IGF-1 concentrations in MSPA and MSPC compared with SBMA-fed calves. Calves fed SBMA had greater DMI, more starch intake, and intermediate CP intake. Bartlett (2006) demonstrated that IGF-1 responds to a greater feeding rate and greater dietary $\mathrm{CP}$ concentration. However, in the current study, we speculate there was less effect of CP intake, which was similar between MSPA and SBMA, and more effect on concentrations of IGF-1 from total intake and starch intake, which were greater for calves fed SBMA.

\section{Apparent Total-Tract Digestibility}

Digestibility of nutrients is inversely related to DMI in cattle (Merchen, 1988; Sarwar et al., 1991). In this study $\mathrm{CP}$ and $\mathrm{ADF}$ digestibilities were greater for calves fed the MSPC diet compared with calves fed SBMA. Greater apparent digestibility by the calves fed MSPC was most likely because of the lesser DMI and slower rate of passage combined with effects of the MSP fungal treatment on protein composition. Increased apparent total-tract digestibility $\mathrm{CP}$ and $\mathrm{ADF}$ may also be because the prebiotic effect from the fungal treatment stimulated rumen development (Lesmeister et al., 2004; Bruce et al., 2015).

\section{CONCLUSIONS}

Calves fed MSP in starter pellets with conventional MR had comparable growth performance to calves fed pellets with SBM and MR formulated for accelerated growth, especially in the preweaning period. Calves fed MSP with MR formulated for accelerated growth had similar growth performance with less starter pellet intake compared with calves fed SBMA. Calves fed MSPC had increased CP and ADF apparent total-tract digestibility compared calves fed SBMA. Findings partially agreed with our hypothesis and demonstrated that feeding MSP as major ingredient in starter pellets has potential to maintain calf performance with less DMI. This was the first study on feeding MSP to calves. More research may be warranted on effects of MSP 
at different inclusion rates in calf pellets and in diets formulated for similar CP amounts among treatments. Also, more in-depth research is needed on how the microbial (fungal) treatment affects protein composition. Additionally, because as all calves were very healthy in this study, it was difficult to determine if MSP has any immune or health benefits as seen in aquaculture research.

\section{ACKNOWLEDGMENTS}

Financial support was provided by the South Dakota Soy Research and Promotion Council (Sioux Falls, SD) and the South Dakota State University Agricultural Experiment Station. Prairie AquaTech (Brookings, $\mathrm{SD}$ ) is acknowledged for providing the microbially enhanced soy protein. This material is based upon work supported by the National Science Foundation under grant number 1256634. The authors thank Ananya Biswas (Dairy Science Department, South Dakota State University) for his help with analyzing lactose in milk replacer. This research contributes to the goals of the USDA North Central Cooperative Research Project NC-2042: Management Systems to Improve Economic and Environmental Sustainability of Dairy Enterprises. We also thank Hugh Chester-Jones of the Department of Animal Science, University of Minnesota (Waseca) for his advice on writing this manuscript.

\section{REFERENCES}

AOAC International. 1995. Official Methods of Analysis. 16th ed. AOAC International, Arlington, VA.

AOAC International. 2002. Official Methods of Analysis. 17th ed. AOAC International, Gaithersburg, MD.

Bach Knudsen, K. E. 1997. Carbohydrate and lignin contents of plant materials used in animal feeding. Anim. Feed Sci. Technol. 67:319 338.

Bartlett, K. S. 2006. Interactions of protein and energy supply from milk replacers on growth and body composition of dairy calves. J. Anim. Sci. 84:1454-1467.

Biswas, A. C., J. K. Amamcharla, and L. E. Metzger. 2011. Rapid measurement of lactose concentration in cheese whey by using handheld blood glucose meter. J. Dairy Sci. 94 (E-Suppl. 1):57.

Brown, E. G., M. J. VandeHaar, K. M. Daniels, J. S. Liesman, L. T. Chapin, D. H. Keisler, and M. S. Weber Nielsen. 2005. Effect of increasing energy and protein intake on body growth and carcass composition of heifer calves. J. Dairy Sci. 88:585-594.

Bruce, T. J., S. C. Sindelar, and M. L. Brown. 2015. Immunomodulation in yellow perch (Perca flavescens) fed bioprocessed soy-based diets with varying inclusion levels of commercial exopolysaccharide. Poster presented at Aquaculture America 2015 (World Aquaculture Society). New Orleans, LA.

Cowles, K. E., R. A. White, N. L. Whitehouse, and P. S. Erickson. 2006. Growth characteristics of calves fed an intensified milk replacer regimen with additional lactoferrin. J. Dairy Sci. 89:48354845.

Daughaday, W. H., I. K. Mariz, and S. L. Blethen. 1980. Inhibition of access of bound somatomedin to membrane receptor and immunobinding sites: A comparison of radioreceptor and radioimmunoas- say of somatomedin in native and acid-ethanol-extracted serum. J. Clin. Endocrinol. Metab. 51:781-788.

Davis, C. L., and J. K. Drackley. 1998. The Development, Nutrition, and Management of the Young Calf. 1st ed. Iowa State University Press, Ames.

Davis-Rincker, L. E., M. J. VandeHaar, C. A. Wolf, J. S. Liesman, L. T. Chapin, and M. S. Weber Nielsen. 2011. Effect of intensified feeding of heifer calves on growth, pubertal age, calving age, milk yield, and economics. J. Dairy Sci. 94:3554-3567.

Dawson, D. P., J. L. Morrill, P. G. Reddy, and H. C. Minocha. 1988. Soy protein concentrate and heated soy flours as protein sources in milk replacer for pre-ruminant calves. J. Dairy Sci. 71:1301-1309.

Echternkamp, S. E., L. J. Spicer, K. E. Gregory, S. F. Canning, and J. M. Hammond. 1990. Concentrations of insulin-like growth factor-I in blood and ovarian follicular fluid of cattle selected for twins. Biol. Reprod. 43:8-14.

Feng, J., X. Liu, Z. R. Xu, Y. P. Lu, and Y. Y. Liu. 2007. Effect of fermented soybean meal on intestinal morphology and digestive enzyme activities in weaned piglets. Dig. Dis. Sci. 52:1845-1850.

Fossati, P., and P. Lorenzo. 1982. Serum triglycerides determined colorimetrically with an enzyme that produces hydrogen peroxide. Clin. Chem. 28:2077-2080.

Funston, R. N., G. E. Moss, and A. J. Roberts. 1995. Insulin-like growth factor-1 (IGF-1) and IGF-binding proteins in bovine sera and pituitaries at different stages of the estrous cycle. Endocrinology 156:52-68.

Gibbons, W. R., and M. L. Brown, inventors. 2012. South Dakota State University, assignee. Microbial-based process for high-quality protein concentrate. US Patent application \#13/691,843.

Hill, T. M., J. M. Aldrich, R. L. Schlotterbeck, and H. G. Bateman II. 2006. Effects of feeding calves different rates and protein concentrations of twenty percent fat milk replacers on growth during the neonatal period. Prof. Anim. Sci. 22:252-260.

Hill, T. M., H. G. Batemann II, J. D. Quigley III, J. M. Aldrich, R. L. Schlotterbeck, and A. J. Heinrichs. 2013. Review: New information on the protein requirements and diet formulation for dairy calves and heifers since the Dairy NRC 2001. Prof. Anim. Sci. $29: 199-207$

Hodgson, J. 1971. The development of solid food intake in calves. 5. The relationship between liquid and solid food intake. Anim. Prod. 13:593-597.

Hoffman, P. C. 1997. Optimum body size of Holstein replacement heifers. J. Anim. Sci. 75:836-845.

Jenny, B. F., H. J. Van Dijk, and L. W. Grimes. 1982. Performance of calves fed milk rations once daily at various fluid intakes and dry matter concentrations. J. Dairy Sci. 65:2345-2350.

Kitchenham, B. A., G. J. Rowlands, R. Manston, and S. M. Dew. 1975. The blood composition of dairy calves reared under conventional and rapid-growth systems. Br. Vet. J. 131:436-446.

Kwon, I. H., M. H. Kim, C. H. Yun, J. Y. Go, C. H. Lee, H. J. Lee, W. Phipek, and J. K. Ha. 2011. Effects of fermented soybean meal on immune response of weaned calves with experimentally induced lipopolysaccharide challenge. Asian-australas. J. Anim. Sci. 3324:957-964.

Leaver, J. D., and N. H. Yarrow. 1972. Rearing of dairy cattle. 2. Weaning calves according to their concentrate intake. Anim. Prod. 14:161-165.

Lesmeister, K. E., A. J. Heinrichs, and M. T. Gabler. 2004. Effects of supplemental yeast (Saccharomyces cerevisiae) culture on rumen development, growth characteristics, and blood parameters in neonatal dairy calves. J. Dairy Sci. 87:1832-1839.

Littell, R. C., G. A. Milliken, W. W. Stroup, R. D. Wolfinger, and O. Schabenberger. 2008. SAS for Mixed Models, 2nd ed. SAS Institute Inc., Cary, NC.

McMurray, C. H., W. J. Blanchflower, and D. A. Rice. 1984. Automated kinetic method for D-3-hydroxybutyrate in plasma or serum. Clin. Chem. 30:421-425.

Merchen, N. R. 1988. Digestion, absorption and excretion in ruminants. Pages 182-189 in The Ruminant Animal: Digestive Physiology and Nutrition. D. C. Church, ed. Prentice Hall Inc., Upper Saddle River, NJ. 
NRC. 2001. Nutrient Requirements of Dairy Cattle. 7th rev. ed. National Academy Press, Washington, DC.

Odle, J., R. T. Zijlstra, and S. M. Donovan. 1996. Intestinal effects of milk borne growth factors in neonates of agricultural importance. J. Anim. Sci. 74:2509-2522.

Quigley, J. D., and J. K. Bernard. 1992. Effects of nutrient source and time of feeding on changes in blood metabolites in young calves. J. Anim. Sci. 70:1543-1549.

Quigley, J. D. III, C. G. Schwab, and W. E. Hylton. 1985. Development of rumen function in calves: Nature of protein reaching the abomasum. J. Dairy Sci. 68:694-702.

R Core Team. 2015. R: A language and environment for statistical computing. R Foundation for Statistical Computing, Vienna, Austria. http://www.R-project.org/.

Robertson, J. B., and P. J. Van Soest. 1981. The detergent system of analysis and its application to human foods. Pages 123-158 in The Analysis of Dietary Fiber in Food. W. P. T. James and O. Theander, ed. Marcel Dekker Inc., New York, NY.

Sarwar, M., J. L. Firkins, and M. L. Eastridge. 1991. Effect of replacing neutral detergent fibre of forage with soy hulls and corn gluten feed for dairy heifers. J. Dairy Sci. 74:1006-1017.

Sindelar, S. C. 2014. Utilization of soybean products as fish-meal protein replacements in Yellow Perch Perca flavescens feeds. MS Thesis, South Dakota State University, Brookings.

Smith, J. L., and L. G. Sheffield. 2002. Production and regulation of leptin in bovine mammary epithelial cells. Domest. Anim. Endocrinol. 22:145-154.

Stamey, J. A., N. A. Janovick, A. F. Kertz, and J. K. Drackley. 2012. Influence of starter protein content on growth of dairy calves in an enhanced early nutrition program. J. Dairy Sci. 95:3327-3336.
Tamate, H., A. D. McGilliard, N. L. Jacobson, and R. Getty. 1962. Effect of various dietaries on the anatomical development of the stomach in the calf. J. Dairy Sci. 45:408-420.

Trinder, P. 1969. Determination of glucose in blood using glucose oxidase with an alternative oxygen acceptor. Ann. Clin. Biochem. 6:24-27.

Vacher, P. Y., G. Bestetti, and J. W. Blum. 1995. Insulin-like growth factor 1 absorption in the jejunum of neonatal calves. Biol. Neonate 68:354-367.

Van Loo, J., J. Cummings, N. Delzenne, H. Englyst, A. Franck, M. Hopkings, N. Kok, G. Macfarlane, D. Newton, M. Quigley, M. Roberfroid, T. van Vliet, and E. van den Heuvel. 1999. Functional food properties of non-digestible oligosaccharides: A consensus report from the ENDO project (DGXII AIRII-CT94-1095). Br. J. Nutr. 81:121-132.

Van Soest, P. J., J. B. Robertson, and B. A. Lewis. 1991. Methods for dietary fiber, neutral detergent fiber, and non-starch polysaccharides in relation to animal nutrition. J. Dairy Sci. 74:3583-3597.

Vazquez-Anon, M., A. J. Heinrichs, J. M. Aldrich, and G. A. Varga. 1993. Effect of post-weaning age on rate of in situ protein disappearance in calves weaned at 5 weeks of age. J. Dairy Sci. $76: 2749-2757$

Wildman, E. E., G. M. Jones, P. E. Wagner, R. L. Boman, H. F. Troutt Jr., and T. N. Lesch. 1982. A dairy cow body condition scoring system and its relationship to standard production characteristics. J. Dairy Sci. 65:495-501.

Wolfswinkel, T. L. 2009. The effects of feeding fermented soybean meal in calf starter on growth and performance of dairy calves. MS Thesis. Iowa State University, Ames. 